УДК 573.01:341.27.29.25.19

Г. М. Кременчуцький, Д. О. Степанський, Л. Г. Юргель, І. П. Кошова, Т. Ю. Крушинська, С. О. Вальчук, А. Ю. Кондратьєв

Дніпропетровська державна медична академія

\title{
ІНФОРМАЦІЙНІ КОМУНІКАЦІї МІКРООРГАНІЗМІВ
}

\begin{abstract}
Макроорганізм у комплексі з мікробіотою розглядається як «суперорганізм». Мікроорганізми, що входять до мікробіоти, перебувають у динамічній рівновазі з макроорганізмом. Ця рівновага досягається завдяки молекулярній «мові» спілкування між прокаріотами та еукаріотичними клітинами. Молекулярне спілкування між клітинами дає позитивні та негативні результати. Виявлено велику кількість метаболітів мікроорганізмів, що несуть інформаційне навантаження (аутоіндукторів). Аутоіндуктори впливають на імунні та різноманітні метаболічні процеси. Цей вплив стосується, практично, всіх органів і систем макроорганізмів. Установлено, що метаболіти аерококів впливають на імунні, регенеративні та інші процеси макроорганізму. Проблема інформаційної комунікації прокаріотів і еукаріотів дає нові уявлення про життсдіяльність «суперорганізмів».
\end{abstract}

Г. Н. Кременчуцкий, Д. А. Степанский, Л. Г. Юргель, И. П. Кошевая, Т. Ю. Крушинская, С. А. Вальчук, А. Ю. Кондратьев

Днепропетровская государственная медицинская академия

\section{ИНФОРМАЦИОННЫЕ КОММУНИКАЦИИ МИКРООРГАНИЗМОВ}

\begin{abstract}
Макроорганизм в комплексе с микробиотой рассматривается как «суперорганизм». Микроорганизмы, входящие в микробиоту, находятся в динамическом равновесии с макроорганизмом. Это равновесие достигается благодаря молекулярному «языку» общения между прокариотическими и эукариотическими клетками. Молекулярное общение между клетками приводит к положительным и отрицательным результатам. Выявлено большое количество метаболитов микроорганизмов, несущих информационную нагрузку (аутоиндукторов). Аутоиндукторы влияют на иммунные и разнообразные метаболические процессы. Это влияние относится, практически, ко всем органам и системам макроорганизмов. Изучены метаболиты аэрококков, влияющие на иммунные, регенеративные и другие процессы макроорганизма. Проблема информационной коммуникации прокариотов и эукариотов дает новые представления о жизнедеятельности «суперорганизмов».
\end{abstract}

G. N. Kremenchutsky, D. A. Stepansky, L. G. Yurgel, I. P. Koshevaya, T. Y. Krushynskaya, S. A. Valchuk, F. Y. Kondratiyev

Dnipropetrovsk State Medical Academy

\section{INFORMATIVE COMMUNICATION OF MICROORGANISMS}

Macroorganism in combination with microbiota is considered as a "superorganism". Microorganisms, belonging to the microbiota, are in dynamic equilibrium with a macroorganism. This balance is achieved through a molecular "language" of communication between prokaryotic and eukaryotic cells. Molecular communication between cells leads to positive and negative results. A large number of metabolites of microorganisms that carry the information load: autoinducers is revealed. Autoinducer affect on the immune systems, and variety of metabolic processes. This affects on practically all organs and systems of macroorganism. Studied metabolites of aerococci affect on the immune system, regenerative cycles and

(C) Г. М. Кременчуцький, Д. О. Степанський, Л. Г. Юргель, І. П. Кошова, Т. Ю. Крушинська, С. О. Вальчук, А. Ю. Кондратьєв, 2010

66 
other processes of macroorganism. The problem of informative communication between prokaryotes and eukaryotes provides new insights about vital functions of "superorganisms".

\section{Вступ}

Завдяки дослідженням численної армії вчених, починаючи з Луї Пастера і до наших днів, організм людини розглядається як «суперорганізм», що складається 3 двох багатокомпонентних систем. По-перше, безпосередньо наш організм, який включає в себе шкіру, слизові оболонки, внутрішні органи, нервову систему i, як ми вважаємо, вершину «вищої» творчості - головний мозок. По-друге, він населений незліченною армією багатоклітинних, одноклітинних, неклітинних мікроорганізмів (гельмінтами, найпростішими, бактеріями, вірусами, бактеріофагами, генетичними елементами i навіть живими білками - пріонами). Часто мікроорганізми, що населяють нас, називають додатковим органом, або мікробіотою.

Мікробіота має детерміновану колоніальну організацію у вигляді біоплівок, в яких одні і ті ж види мікробів представляють різні клітинні кластери з вертикальним шаруванням i горизонтально розділеними зонами. $\mathrm{y}$ колоніальній організації мікроорганізмів усередині біоплівок є системи повітроносних мікропорожнин, що перетинаються клітинними тяжами. Для колоній мікроорганізмів характерне формування функціональних органів надорганізмового рівня, що відіграють комунікаційну, захисну, структуротвірну ролі [4].

В. Г. Войцеховським було встановлено, що диференціація клітин бацил відбувається в їх агрегатах, тобто своєрідних біокомплексах. Молекулярним сигналом для розвитку культур служать аутобіополімери глікопротеїдної природи з молекулярною масою 41,0 і 33,5 кДа. Агрегація ініціюється специфічними поверхневими білками клітинної стінки (70,0-72,0 кДа) [2].

У людському організмі «працюють» понад 2 млн. різних хімічних молекул (понад 100 тис. різних білків, 250 тис. ліпідів та інших біологічно активних речовин), гармонійна взаємодія яких і визначає зростання, розвиток і здоров'я людини [11]. Значна кількість цих молекул синтезується та вивільняється мікроорганізмами, які постійно або тимчасово присутні на їі шкірі та слизових оболонках.

\section{Роль мікробіоценозів у життсдіяльності «суперорганізму»}

На організм людини постійно діють різні «шкідливі» ендогенні та екзогенні фактори (склад їжі, лікарські препарати, захворювання, інші хімічні, фізичні та біологічні агенти, стресові стани тощо). У тих випадках, коли за своєю тривалістю та інтенсивністю негативні впливи перевищують компенсаторні можливості системи «господар - його мікрофлора», виникають порушення, так званий «дисбактеріоз» [7].

Від мікроорганізмів, що населяють нас, залежить злагоджена робота всіх інших органів. Будь-які порушення цієї координованої роботи, що виходять за межі компенсаторних можливостей «суперорганізму», приводять спочатку до функціональних змін фізіологічних функцій і метаболічних реакцій, а потім - до розвитку різноманітних захворювань. Основну функцію взаємодії 3 нашим організмом виконують пробіотичні мікроорганізми (pro bios - для життя), на відміну від антибіотиків (anti bios - проти життя).

Однак існують інші молекулярні сигнали, що порушують роботу макроорганізму. Зокрема, специфічні ділянки мембран грамнегативних бактерій здатні активувати різні типи клітин макроорганізму, які залучаються до патогенезу сепсису. Так званий ліпід $A$, естерифікований глюкозамін, спільно 3 пірофосфатами та жирними кислотами, пов'язаними 3 ефірними й амідними групами, формує частину ліпополісахаридної клітинної мембрани. Ця сигнальна частина бактерій формує септичний синдром [8]. 
Для профілактики та відновлення порушень мікробіоти у світі розроблені та впроваджені у практику понад сто різних пробіотичних лікарських препаратів, біологічно активних добавок і функціональних продуктів харчування. Молекулярні та біохімічні механізми впливу пробіотиків на організм людини багато в чому залишаються не розпізнаними. Залишається незрозумілим, як споживання декількох грамів пробіотичних мікроорганізмів веде до настільки значущих позитивних змін фізіологічних функцій і здоров'я людини в цілому [7].

\section{Явище транслокації мікроорганізмів і їх метаболітів}

У 1990-х роках установлено, що через слизову оболонку кишечника можуть легко проникати різні мікроорганізми, фрагменти їх клітин, колоїдні частинки, гранули харчового крохмалю, інші сполуки, близькі за розміром до бактеріальних клітин або менші. У результаті подібні частки та молекули легко виявляються в крові та сечі людини. Їх появу у біологічних рідинах можна виявити вже протягом декількох хвилин після орального введення тих або інших індикаторних сполук або мікроорганізмів [10].

Експериментально доведено, що мікроорганізми травного тракту здатні активно переробляти складні речовини, що надходять ззовні (харчові продукти) або мають ендогенне походження (компоненти слини, травних соків, злущений епітелій, мертві мікроорганізми тощо). Мікробна трансформація різних субстратів приводить до утворення у травному тракті багатьох сотень (можливо, тисяч) низькомолекулярних біологічно активних функціональних інгредієнтів [9].

Транслокація (тобто проникнення до внутрішнього середовища) бактерій, фрагментів їх клітин і метаболітів, так само як і низькомолекулярних сполук, що утворюються в результаті мікробної деградації епітеліальних клітин, вмісту мукозного шару, харчових субстратів із просвіту кишечника до біологічних рідин, - звичайний фізіологічний процес. Біологічно активні сполуки, пов'язані 3 пробіотичними мікроорганізмами, здатні модифікувати практично будь-які метаболічні реакції в організмі, причому механізми їх впливу різні для різних пробіотиків [10].

\section{Кворум-системи мікроорганізмів}

Системи, що регулюють внутрішні та міжпопуляційні мікробні взаємодії та взаємовідносини бактерій з клітинами господаря, отримали назву Quorum sensing (QS). QS є специфічним варіантом регуляції експресії різних генів, за допомогою яких мікроорганізми здатні розпізнавати навколишнє середовище, взаємодіяти між собою і 3 клітинами господаря через низькомолекулярні сигнальні молекули, так звані аутоіндуктори (хемокініни, модуліни). Ці молекули запускають каскад процесів у прокаріотичних та еукаріотичних клітинах, коли ї кількість досягає певного рівня (quorum). Аутоіндуктори взаємодіють із клітинними регуляторними білками, розпізнають їх i, в кінцевому рахунку, активують (індукують) роботу (експресію) відповідних генів. Завдяки аутоіндукторам бактерії та клітини господаря обмінюються інформацією та координують свою діяльність. Ось чому подібні сигнальні молекули розглядають як «слова» в інформаційній молекулярній «мові». Численні дослідження останніх років показали, що мікроорганізми, включаючи пробіотичні бактерії, синтезують і розпізнають широкий спектр аутоіндукторів різної хімічної природи.

Відомі і потенційні аутоіндуктори пробіотичних бактерій: лактони; пептидні феромони; індуктори АI типу, включаючи фуранони; летючі жирні й інші органічні кислоти; певні групи ферментів (лактонази, глікозидази, оксидази); стресові білки; білки та пептиди, що імітують сигнальні молекули еукаріотичних клітин; деякі амінокислоти 
(глутамат, бета-аланін); вітаміни (біотин); аміни (гістамін, серотонін) і поліаміни (спермін, спермідин); деякі ліпополісахариди (пептидоглікан, ліпотейхоєва кислота); антимікробні агенти (бактеріоцини, мікроцини, оксид азоту, активні форми кисню); лектини; біосурфактани $[1 ; 5 ; 6]$.

\section{Функціональна та інформаційна роль аерококів, що входять до складу пробіотичного препарату «А-бактерин»}

Найвідоміші пробіотичні препарати, розроблені десятиріччя тому - колібактерин, біфідумбактерин і лактобактерин. Технологія приготування цих препаратів заснована на їх вирощуванні на живильному середовищі, змиві з живильного середовища та висушуванні за допомогою ліофільного сушіння. При цьому бактерії занурюються в глибоку «сплячку» (те саме, що анабіоз), що дозволяє їх довгостроково зберігати. Але при цьому при вживанні вони навіть не встигають «прокинутися» і виводяться 3 нашого організму, так і не виконавши свого призначення. Тому останніми роками розроблено так звані живі рідкі пробіотичні препарати, що містять у своєму складі й аутоіндуктори, й живі клітини, готові до негайного спілкування з нашими клітинами та позитивного впливу на організм.

До цих препаратів належить розроблений вченими та практичними мікробіологами Дніпропетровська «A-бактерин» (оригінальний, який не має аналогів, пробіотичний препарат) [3]. Характерна його особливість - підвищена ефективність при корекції дисбактеріозів і нормалізації багатьох функцій макроорганізму за рахунок аутоіндукторів.

Бактеріальну та бактеріостатичну дію «A-бактерину» зумовлюють його адгезивні властивості, комплекс біологічно активних речовин, синтезованих аерококами (низькомолекулярні пептиди (віридоцини) та інші біологічно активні продукти, сигнальні для мікробіоти та клітин макроорганізму. Препарат виявляє лікувально-профілактичну дію при дисбактеріозах кишечника різної етіології, бактеріоносійства, хронічних колітів, у тому числі неспецифічних. За рахунок аутоіндукції відновних процесів у мікробіоті «A-бактерином» спостерігається повне відновлення нормальної мікрофлори товстого кишечника хворих на дисбактеріоз за основними пробіотичними мікроорганізмами (біфідумбактерії, лактобактерії, колібактерії).

Особливість «A-бактерину» - його здатність стимулювати регенеративні процеси у гнійних і опікових ранах, підвищувати фагоцитарну активність нейтрофілів і нормалізувати інші показники макроорганізму, зокрема, знижувати вміст холестерину в крові. Аерококи, що входять до складу препарату, окислюють молочну кислоту в порожнині рота, знижуючи здатність зубної бляшки демінералізувати зубну емаль. Нейтралізація одного 3 метаболітів рафінованих вуглеводів має для гомеостазу порожнини рота коригувальне значення, оскільки втручається в тонкі механізми патогенезу карієсу зубів.

У пацієнтів, що вживали «A-бактерин», виявлено зниження рівня молочної кислоти та холестерину крові, інтенсивності перекисного окислення ліпідів, концентрації в сироватці крові $a$-інгібітора протеїназ та інгібітора трипсину. Це розширює показання застосування препарату при захворюваннях, що супроводжуються підвищенням активності протеолізу: гострі, підгострі та хронічні інфекції; відновна фаза термічних опіків; на тлі вакцинації; хронічна втома тощо. Як установили алергологи, «A-бактерин» серед своїх безсумнівних переваг володіє антиалергічною дією та показаний для зниження алергічних реакцій у весняний, літній та осінній сезони.

Ці дані підтверджують високу інформаційну роль аерококів у системі «суперорганізму». Якщо взяти до уваги функціонуючі мільйонні популяції мікроорганізмів у 
«суперорганізмі», стає ясним, наскільки складна інформаційно-молекулярна мережа, яка охоплює всі види життєдіяльності, і абсолютно не вивченими залишаються регуляторні системи, які утримують в рамках цієї мережі біохімічний гомеостаз.

\section{Висновки}

Система «мікроорганізми - макроорганізм» повинна розглядатися в функціональній, морфологічній та інформаційній єдності як «суперорганізм». Колоніальна та біоплівчаста організація мікробних спільнот у макроорганізмі має складну багаторівневу структуру, що забезпечує щільний взаємозв'язок із макроорганізмом. «Суперорганізм» протистоїть шкідливим впливам навколишнього середовища, які включають екологічні, хімічні, радіаційні фактори, патогенні мікроорганізми, а також коригує внутрішні порушення, що призводять до хвороб.

Виявлена транслокація мікроорганізмів і їх метаболітів у внутрішній системі макроорганізму грає як позитивну роль, стимулюючи імунні процеси, так і негативну при розвитку неспецифічних запальних процесів. Численні аутоіндуктори, синтезовані мікробіотою, утворюють інформаційно-біохімічну мережу з продуктами метаболізму макроорганізму, спільно регулюючи роботу органів і систем «суперорганізму». У результаті досліджень виявлено, що «A-бактерин» синтезує численні аутоіндуктори активатори, які виконують роль міжбактеріальної та міжвидової мови; це дозволяє регулювати фізіологічні та метаболічні процеси в мікробіоті та макроорганізмі.

\section{Бібліографічні посилання}

1. Вахитов Т. Ю. Концепция пробиотического препарата, содержащего оригинальные микробные метаболиты / Т. Ю. Вахитов, Л. Н. Петров, В. М. Бондаренко // Микробиология. - 2005. № 5. - С. 108-114.

2. Войцеховський В. Г. Агрегати бактерій періодичної культури та їх стійкість до антимікробних речовин // Вісник Вінницького держ. мед. ун-ту. - 2000. - № 2. - С. 278-279.

3. Кременчуцький Г. М. Спосіб одержання рідкого пробіотика з аерококів / Г. М. Кременчуцький, С. А. Риженко. - Патент на винахід № 85272. - 12.01.2009. - Бюл. № 1.

4. Межклеточная коммуникация у бактерий и перспективы создания на ее основе антибактериальных препаратов нового поколения / А. Я. Цыганенко, Н. И. Коваленко, С. И. Степаненко, В. Н. Васильченко. - Харьков : ХГМУ, 2004. - 32 с.

5. Хмель И. А. Экспрессия Quorum sensing генов - перспективная мишень для лекарств в отношении патогенности бактерий / И. А. Хмель, А. З. Метлицкая // Молекулярная биология. 2006. - Т. 40, № 2. - С. 195-210.

6. Шендеров Б. А. Базовые механизмы регуляции гомеостаза и их модуляция нутриентами // Клиническая медицина (Санкт-Петербург). - 2004. - № 3. - С. 14-19.

7. Шендеров Б. А. Функциональное питание и его роль в профилактике метаболического синдрома. - М. : ДеЛи принт, 2008. - 319 с.

8. Bone R. C. Sepsis syndrome. Part 1: The diagnostic challenge / Journal of Critical Ilness. - 1991. N 6. - P. 525-539.

9. Corthesy B. Cross-talk between probiotic bacteria and the host immune system / B. Corthesy, H. R. Gaskins, A. Marcenier // J. Nutr. - 2007. - Vol. 137. - P. 7815-7905.

10. Freter R. Factors affecting the colonization of the gut by lactobacilli and other bacteria / R. Freter, M.-E. Nader de Macias // Probiotics. Prospects of Use in Opportunistic Infections (Eds. R. Fuller et al.). Old Herborn University Seminar. - 1995. - N 8. - P. 19-34.

11. Proteomic and its role in nutrition research / J. Wang, D. Li, L. J. Dangott, G. Wu // J. Nutr. - 2006. Vol. 136, N 7. - P. 1759-1762.

Надійшла до редколегї̈ 28.06.2010 